\title{
Putrescine and Spermine Affects the Postharvest Storage Potential of Banana Cv. Grand Naine
}

\author{
T.J. Archana ${ }^{1} *$ and G.J. Suresh ${ }^{2}$ \\ ${ }^{1}$ Department of Postharvest Technology, Kittur Rani Channamma College of Horticulture, \\ UHS, Bagalkot, Arabhavi-591218, Karnataka, India \\ ${ }^{2}$ Department of Postharvest Technology, COH, Bengaluru, UHS Campus, GKVK Post- \\ 560065, Karnataka \\ Indian Agriculture Research Institute, New Delhi -110012, India \\ *Corresponding author
}

\begin{abstract}
A B S T R A C T
Keywords

Putrescine,

Spermidine, Shelf

life, Postharvest

physiology, Banana,

Polyamine

Article Info

Accepted:

26 December 2018

Available Online:

10 January 2019

A study was conducted to evaluate the efficacy of exogenous application of putrescine and spermine (Polyamine) on postharvest physiological and biochemical behavior of banana cv. Grand Naine. Mature unripe bananas were dipped in varied concentrations of putrescine (PUT) (1 mM, $3 \mathrm{mM}$ and $6 \mathrm{mM})$ and spermine (SPM) $(1 \mu \mathrm{M}, 5 \mu \mathrm{M}$ and $10 \mu \mathrm{M})$ aqueous solution and stored at cold storage $\left(13{ }^{\circ} \mathrm{C} \pm 1,85 \% \mathrm{RH}\right)$. Dipping of bananas in distilled water served as control. The physiological and biochemical parameters were recorded at 7 days interval after subsequent ripening under ambient conditions $(7+18,14$ $+12,21+7$ and $28+5$ days). Results revealed that among treatments $5 \mu \mathrm{M}$ spermine was more effective in reducing the physiological loss in weight $(4.06 \%)$, fruit softening (991.18g), colour change, delayed the biochemical changes by decreasing the conversion of starch $(3.61 \%)$ into sugars $(16.53 \%)$, and reduced the consumption of organic acids which was witnessed by low respiration rate $(123.84 \mathrm{ml} \mathrm{CO} / \mathrm{kg} / \mathrm{h})$, highest value for ascorbic acid $(13.69 \mathrm{mg} / 100 \mathrm{~g})$ and titratable acidity $(0.396 \%)$ while maintaining good organoleptic qualities. Thus, the exogenous application of polyamines could be effective as a postharvest tool in maintaining the quality and shelf life of banana cv. Grand Naine.
\end{abstract}

\section{Introduction}

Banana, a fruit of tropics is so prominent and popular owing to its nutritive value and cheapest among the fruits grown. Bananas are harvested at mature green stage and ripened under controlled conditions at destination market. The ripened banana is soft, and highly perishable with postharvest loses estimated to be more than $25 \%$ (28) and marketable life of ripened banana turns into unmarketable in only 1-3 days (32). Though India is the largest producer (Annual production of 297.24 lakh tones), contribution to global market is insignificant. Most of the bananas are consumed in the country and only $20 \%$ are 
exported. The physiological changes that occur after fruit ripening, restricts the handling and transportation.

The fruit ripening can be delayed by lowering the storage temperature and using special chemicals. Banana fruits suffer chilling injury at a very low temperature and use of chemicals has led to many health hazards. Thus, there is a need for a safe bio-based chemical which can delay ripening.

Deterioration of fruit quality physiologically correlates with reduction of polyamine (PA) content in the ripening fruits and increase in ethylene production as both polyamine and ethylene share the common precursor $S$ adenosyl methionine $(5,20)$. Much research evidences have shown that exogenous polyamines can inhibit ethylene biosynthesis and thereby delay the ripening process (11). Polyamines are biological compounds of low molecular weight in their free forms which act as anti-senescent agents, delay ethylene production, reduce rate of respiration, increase fruit firmness, induce mechanical resistance, reduce chilling symptoms and retard colour changes (30).

The major polyamines found in every plant cell are spermidine (spd), spermine (spm) and putrescine (put) (7). Previously, exogenous application of PUT and SPM(PAs) has been reported to improve shelf life and quality in many climacteric and non-climacteric fruits like plum (24), apricot (8), strawberries (13), Kiwifruit (10); Mango (12, 15), Peach (2), Pomegranate (1) and Blood orange (6). It has been observed that much of the research findings are available on temperate fruits. The research findings on usefulness of exogenous application of polyamines on tropical fruits like banana are lacking and needs thorough investigation. The purpose of this study is to elucidate the effective utilization of PUT and SPM as a postharvest tool with an aim to improve the quality and shelf life of banana cv. Grand Naine under cold storage conditions $\left(13{ }^{\circ} \mathrm{C} \pm 1\right)$.

\section{Materials and Methods}

\section{Fruit material and treatments with polyamines}

Banana fruits cv. Grand Naine was procured from Department of Fruit science of Kittur Rani Channamma College of Horticulture, Arabhavi, Belgaum (District), Karnataka, India. Fruits of uniform size, shape, maturity free from any visible blemishes and diseases were sorted to maintain the uniformity. Further the fruits were washed in clean water and air dried under electric fan. The surface air dried fruits were sanitized with 0.2 per cent sodium hypochlorite solution for five minutes and used for the further experiment. The different concentration of PUT and SPM was prepared out of the stock solution of $10 \mathrm{mM}$ and $1 \mathrm{mM}$, respectively. The tween $20(0.1 \%)$ was added with the aqueous solutions. The fruits were immersed in different concentrations of PUT (1 mM, 3 mMand 6 $\mathrm{mM})$ and SPM (1 $\mu \mathrm{M}, 5 \mu \mathrm{M}$ and $10 \mu \mathrm{M})$ separately for 30 minutes and air dried under electric fan. The distilled water served as a control. The cut crown portion plugged with cotton treated with 0.1 per cent carbendazim to control the crown rot. The fruits were packed in polythene cover, placed in ventilated corrugated fiber board boxes (CFB) and stored at cold storage $\left(13 \pm 1^{\circ} \mathrm{C}\right.$ and 85 per cent relative humidity). The samples were examined at an interval of 7, 14, 21 and 28 days. At the end of the each interval fruits were taken out from the cold room and held at room temperature to facilitate natural ripening. The days taken to ripen at ambient condition varied after each interval period.

\section{Physiological loss in weight}

The cumulative loss in weight of fruits were calculated and expressed as per cent 
physiological loss in weight using the formula, Physiological loss in weight $(\%)=(($ initial weight- final weight)/ initial weight $) \times 100$.

Firmness, respiration rate and colour $\left(\mathrm{L}^{*}\right.$ $\mathbf{a}^{*} \mathbf{b}^{*} \mathbf{C}^{*} \mathbf{h}^{\circ}$ )

Firmness was measured using Lutron FG$5000 \mathrm{~A}$ penetrometer. Respiration rate $(\mathrm{ml}$ $\mathrm{CO}_{2} / \mathrm{kg} / \mathrm{h}$ ) was measured by static method using gas analyzer (PBI, DANSENSOR, CHECKMATE 2). The colour was measured using a Lovibond colour meter (Lovibond RT300, Portable spectrophotometer, The Tintometer Limited, Salisbury, UK) fitted with Xrite 962 sensor, $8 \mathrm{~mm}$ diameter aperture, D65 illuminant and $10^{\circ}$ observer. The Colour was expressed in Lovibond units $L^{*}$ (Lightness/darkness), $a^{*}$ (redness/ greenness), $b^{*}$ (yellowness/blueness), $C^{*}$ (chroma) and $h^{\circ}$ (hue angle).

\section{TSS and pulp to peel ratio}

TSS was determined using Erma hand refractrometer. Pulp and peel were separated and weighed separately and expressed as pulp to peel ratio (pulp weight/ peel weight).

Titratable acidity (\%), Ascorbic acid (mg / $100 \mathrm{~g})$, Total sugars (\%) and Starch (\%)

Quality components like titratable acidity, ascorbic acid, total sugar and starch are estimated according to standard methods (22).

\section{Organoleptic evaluation (5-point Hedonic scale)}

The organoleptic evaluation was carried out by a panel of six semi-trained judges. The sensory characters like skin colour as well as colour and appearance, texture, taste and flavour, and overall acceptability of flesh were evaluated on a 5 point Hedonic scale. The mean of scores given by the judges were used for statistical analysis.

\section{Statistical analysis}

The data were subjected to statistical analysis in completely randomized design using ICAR research complex for Goa (Web Agri Stat package 2). The level of significance used in ' $F$ ' test was $p=0.05$. Critical difference values were calculated wherever ' $F$ ' test was significant (21).

\section{Results and Discussion}

In the present study the parameters were analyzed after fruits were fully ripened under ambient conditions. The fruits when stored for 7 and 14 days under cold storage took 18 and 12 days for complete ripening process, respectively. In contrary to this the fruits ripened within 7- 5 days when stored for 21 and 28 days. However, the effect of treatments was same during all the storage period. Hence the results after 28 days of cold storage are taken as example to explain the impact of the treatments.

\section{Physiological loss in weight}

The Exogenous polyamine reduced the weight loss compared to the control. The exogenous SPM application expressed more efficacy than PUT in inhibiting weight loss. With regard to different concentrations, $0.5 \mu \mathrm{M}$ SPM $(4.06 \%)$ recorded the lowest value (Fig. 1a). On contrary, untreated fruits registered maximum value $(13.74 \%)$. The water loss (transpiration) and utilization of reserved foods (Respiration) during metabolic process are the main attributes of weight loss during postharvest storage. The stomata on banana skin and cellular breakdown hasten transpiration. The lower weight loss in PUT and SPM treated fruits is the consequence of consolidation and stabilization of both cell integrity and permeability of the tissues as polyamine forms linkage with cell membranes and preserves waxes of cuticle layer there by retard the 
removal of epicuticular waxes which play a very important role in water exchange through the skin (18). Low rates of respiration and reduced ethylene production are also the reason for this phenomenon $(27,4)$.

\section{Firmness (g)}

The treated fruits had higher firmness value compared to the control fruits. After the 28 days of the storage period the maximum firmness was retained in $0.5 \mu \mathrm{M}$ SPM (991.18 g) followed by $1 \mathrm{mM}$ PUT $(903.95 \mathrm{~g})$ and 10 mM SPM (873.09 g). Correspondingly, lowest firmness was registered in untreated fruit (283.81g) (Fig. 1b). Fruit softening could arise from one of the three mechanisms; loss of turgor; degradation of starch; or breakdown of the fruit cell walls. In banana, the degradation of starch probably results in fruit texture change. The effects of polyamines could be due to modification of genes involved in ethylene biosynthesis, ethylene perception, alteration of cell wall associated enzymes and polyamine conjugation (23). According to Valero (30) rigidification of cellwall is a reason for maintaining fruit firmness in treated fruits, which is result of cross-linkage between polyamine and carboxyl group of the pecitc substances in the cell wall. The bindings between polyamines and pectin also inhibit the activity of cell wall degrading enzymes, such as pectinesterase, pectin methylesterase and polygalacturonase and reduced fruit softening during storage.

\section{Pulp to peel ratio}

Pulp to peel ratio is a good and consistent index of ripening of banana. The minimum pulp to peel ratio was observed in polyamine treated fruits in comparison to untreated fruits. Among all the treatments the lowest value was found in banana fruits treated with $5 \mu \mathrm{M}$ SPM (1.96) followed by $1 \mathrm{mM}$ PUT (2.19). Whereas, the untreated fruits (3.06) expressed maximum pulp to peel ratio (Fig. 1c). Changes in pulp to peel ratio during ripening of banana indicate differential changes in moisture content of the peel and pulp. The differential changes in the pulp to peel during ripening indicate different concentration of sugars in the two tissues. As the fruit ripen the sugar concentration of pulp increases rapidly, which leads to flow of moisture from peel to pulp as a result differential changes in osmotic pressure. The peel loses water to the pulp by osmosis and also to the atmosphere through transpiration, thereby contributing to an increase in the fresh weight of the pulp (29). The lowest pulp to peel ratio in PUT and SPM treated fruits may be attributed to delay in ripening compared to control.

\section{Respiration rate $(\mathrm{ml} \mathrm{CO2} / \mathrm{kg} / \mathrm{h})$}

The exogenous application of polyamines reduced the rise in respiration rate compared to the control. The fruits treated with $5 \mu \mathrm{M}$ SPM (123.84 $\left.\mathrm{ml} \mathrm{CO}_{2} / \mathrm{kg} / \mathrm{h}\right)$ expressed a minimum respiration rate which was closely followed by $1 \mathrm{mM}$ PUT (134.62 $\mathrm{ml} \mathrm{CO}$ $/ \mathrm{kg} / \mathrm{h})$ and $10 \mu \mathrm{M} \mathrm{SPM}(140.33 \mathrm{ml} \mathrm{CO} / \mathrm{kg} / \mathrm{h})$ after 28 days of cold storage with 5 days of subsequent ripening (Fig. 1d). On the contrary, the highest respiration rate value is noticed in untreated fruits $(188.73 \mathrm{ml}$ $\mathrm{CO}_{2} / \mathrm{kg} / \mathrm{h}$ ). The minimum respiration rate in PUT and SPM treated fruits is mainly due to its anti-senescence properties, inhibition of ethylene biosynthesis or reduced rate of metabolism and favourable water activity (1, $3)$. The results are in conformity with many reports $(16,3-5)$.

\section{$\operatorname{Colour}\left(\mathrm{L}^{*}, \mathbf{a}^{*}, \mathbf{b}^{*}, \mathbf{C}^{*}, \mathbf{h}^{0}\right)$}

The banana is characterized by the green colour at the maturity stage which changes to yellow colour on ripening. During storage period the $L^{*}, a^{*}, b^{*}$ and $C^{*}$ values increased and $h^{0}$ declined compared to the initial value. 
This might be due to the chlorophyll degradation, which subsequently reveals the yellow carotenoid pigments (25). The negative value of $a *$ indicates greenness of peel colour and the positive value represents the loss of greenness (Fig. 2e). The colour parameter $b^{*}$ represents yellowness hence it has been described as best to reflect the colour changes in skin tissues during fruit ripening (17) (Fig. $2 \mathrm{~d})$. The higher values of $b^{*}$ represents fully ripened yellow colour fruit. The intensity of chroma (Fig. 2c) and purity of the hue (Fig. $2 \mathrm{~d})$ represents the brightness of the fruits (26). The minimum $L^{*}$ value (73.77), $a^{*}(-0.43)$, $b^{*}$ (49.44), $C^{*}(39.44)$ and maximum $h^{0}(90.76)$, was observed in the fruits treated with the 5 $\mu \mathrm{M}$ SPM followed by $1 \mathrm{mM}$ PUT. Whereas the untreated fruits expressed the contrast with maximum values $(84.49,8.60,49.44,49.44$, for $L^{*}, a^{*}, \quad b^{*}$ and $\quad C^{*}$ respectively and minimum for $h^{0}(80.41)$. The delay in fruit colour development in treated fruits indicates the lower chlorophyll degradation, delay in carotenoids biosynthesis and senescence. The inhibition of peroxidase activity by polyamines contributes to lower chlorophyll degradation. Earlier, the retardation of chlorophyll loss in musk melon with exogenous application of polyamines has been attributed to reduced hydrolytic activities acting on chloroplast thylakoid membranes (14). The results are in line with the data reported in lemon and apricot $(17,31)$, mango (15), grapes (3).

\section{Total soluble solids ( $\left.{ }^{0} \mathrm{~B}\right)$, Titratable acidity (\%), Ascorbic acid (mg/100g)}

The TSS, TA and ascorbic acid of banana fruits (cv. Grand Naine) was significantly affected by the polyamine treatments. The data revealed that the minimum TSS (15.46 ${ }^{0}$ B) (Fig. 3a), ascorbic acid (13.69 mg/100g) (Fig. 3b) and maximum titratable acidity (0.39\%) (Fig. 3d) was observed in $5 \mu \mathrm{MSPM}$ whereas the contrary values were elicited in untreated fruits (TSS- $23.34{ }^{0} \mathrm{~B}$; ascorbic acid
$-11.23 \mathrm{mg} / 100 \mathrm{~g}$ and TA-0.27\%). The soluble solids ascorbic acid and titratable acidity could be a useful index of maturity or stage of ripeness. As ripening advances, acidity declines presumably due to the utilization of organic acids as respiratory substrates (25). The increased acidity in banana fruits during ripening might due to an obstruction in protein transfer as the fruit ripen. The delayed changes in TSS, titratable acidity and ascorbic acid is attributed to slower conversion of starch to sugar, suppression of ascorbate oxidase activity (16), reduction or delay in ethylene production, and in turn the delay of ripening.

\section{Total sugar (\%) and starch (\%)}

Hydrolysis of starch and accumulation of sugars are the most striking chemical changes that occur during the post-harvest ripening of banana fruit. In the present study, the fruits treated with $5 \mu \mathrm{M}$ SPM (3.61\%) had maximum starch content and minimum total sugar percentage (16.53 and 17.72, respectively). The untreated fruits expressed lowest value for starch $(2.01 \%)$ and highest value for total sugar (22.34 \%) (Fig. 4a and $4 \mathrm{~b})$. The results indicated that the conversion of starch into sugars was rapid in untreated fruits than treated fruits. The postulate of effect of PUT and SPM on maximum per cent of starch content is slow hydrolysis of starch due to delayed ripening and senescence process. An increase in amylase and phosphorylase activities is strongly correlated with starch degradation during banana ripening (9). The PAs may affect the activities of such enzymes involved in starch metabolism. Effects of PAs on the activities of amylase and phosphorylase are yet to be investigated. Exogenous spermine induces higher accumulation of PUT and SPD, which could be attributed to an up regulation of arginine decarboxylase, a key enzyme for polyamine biosynthesis (19). Finally, the increased level of endogenous polyamine could be responsible for lower sugars per cent. 
The polyamines applied exogenously increase the endogenous PAs and reduce the rates of respiration (30) and ethylene production (1, 24) thus inhibiting ripening related changes within the fruit resulting in delayed increase of sugars in PUT and SPM treated banana (cv. Grand Naine) fruits. Malik and Singh (23) reported that the lower sugar content in the PAs treated fruits compared to control may be due to slower conversion of starch to sugars.

\section{Organoleptic evaluation}

The maximum scores for sensory attributes is recorded by $5 \mu \mathrm{M}$ SPM, while, the minimum score is gained by untreated fruits (Fig. 5). During the ripening of banana, the flesh colour changes from the typical "opaque white" to a "very soft yellow". As PUT and SPM treated fruits had maximum per cent of starch in comparison to the control the fruit showed the "opaque white" colour and scored high in comparison to control fruits. This colour change could be used to ascertain pulp texture during maturation. The hard green fruit turns into a yellow with soft internal pulp and become mushy as it advances towards senescence. The lower score for untreated fruits might be due to mushy soft texture due to over ripening. While, the highest score for PUT and SPM treated fruits is due to maximum firmness of the fruits. This is evident from the maximum firmness value in PUT and SPM treated fruits.

Figure.1 Effect of putrescine and spermineon PLW (a), firmness (b), pulp to peel ratio (c) and respiration rate (d)of banana cv. Grand Nainestored at $13{ }^{\circ} \mathrm{C} \pm 1$ followed by ripening at room temperature. The results represent the mean of 3 fruits \pm S.E

$1(\mathrm{a})$

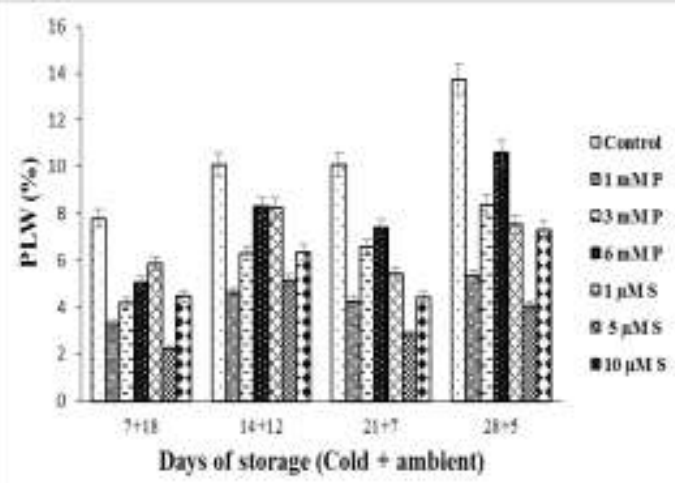

$1(\mathrm{c})$

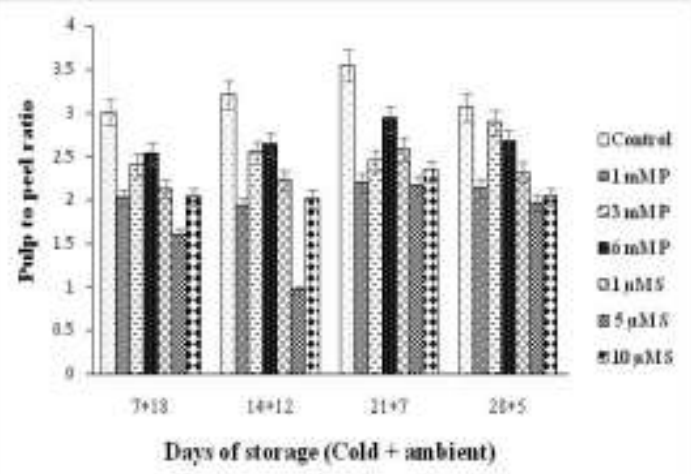

$1(\mathrm{~b})$

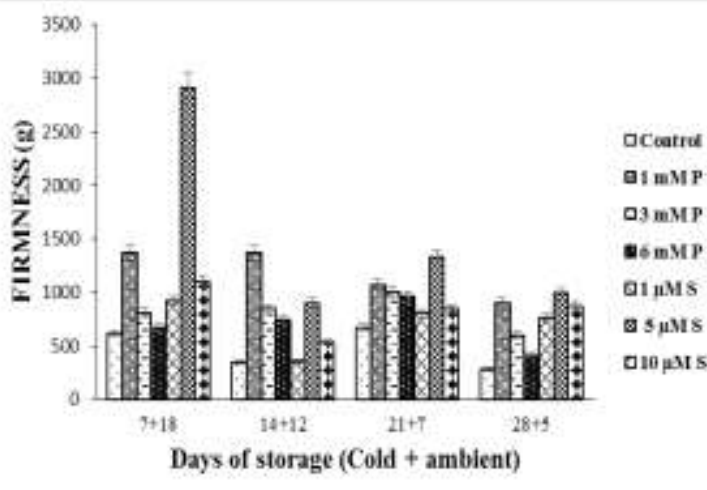

$1(\mathrm{~d})$

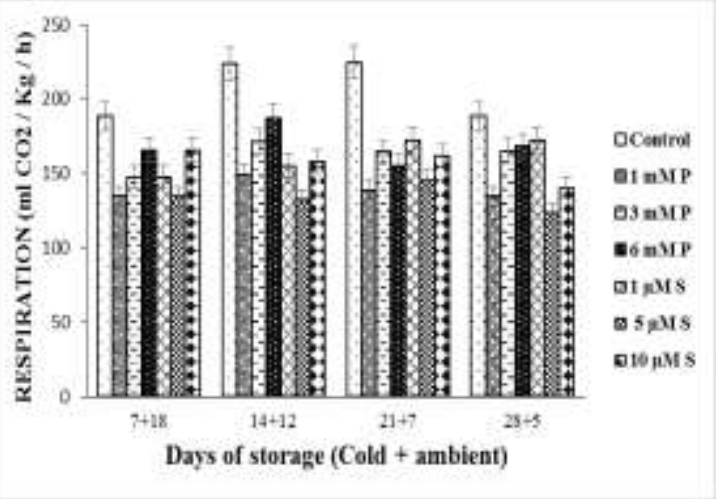


Figure. 2 Effect of putrescine and spermine on $L^{*}(\mathrm{a}), b^{*}(\mathrm{~b}), C *(\mathrm{c}), h^{o}(\mathrm{~d})$ and $a *(\mathrm{e})$ of banana cv. Grand Naine stored at $13{ }^{\circ} \mathrm{C} \pm 1$ followed by ripening at room temperature. The results represent the mean of 3 fruits \pm S.E
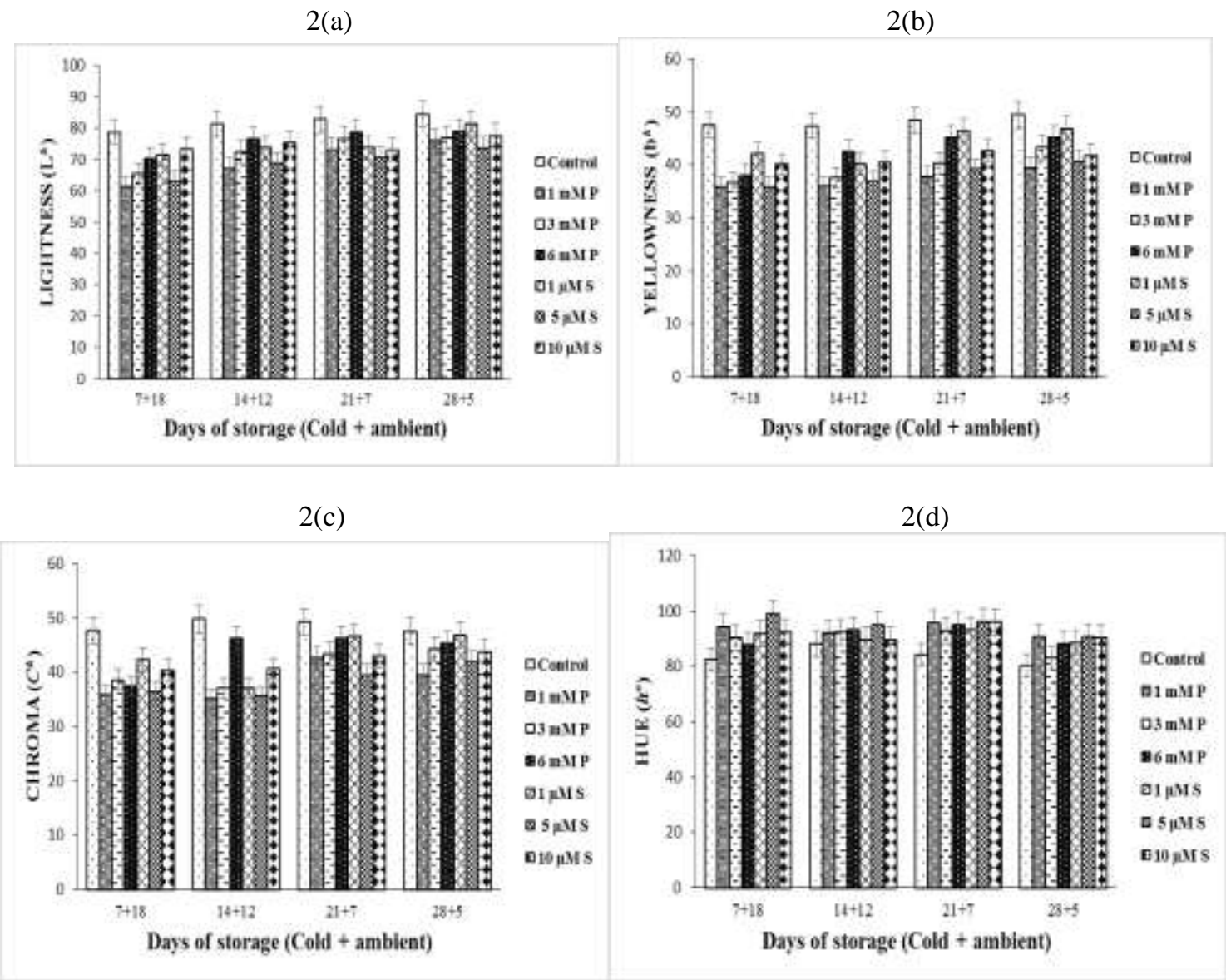

$2(\mathrm{e})$.

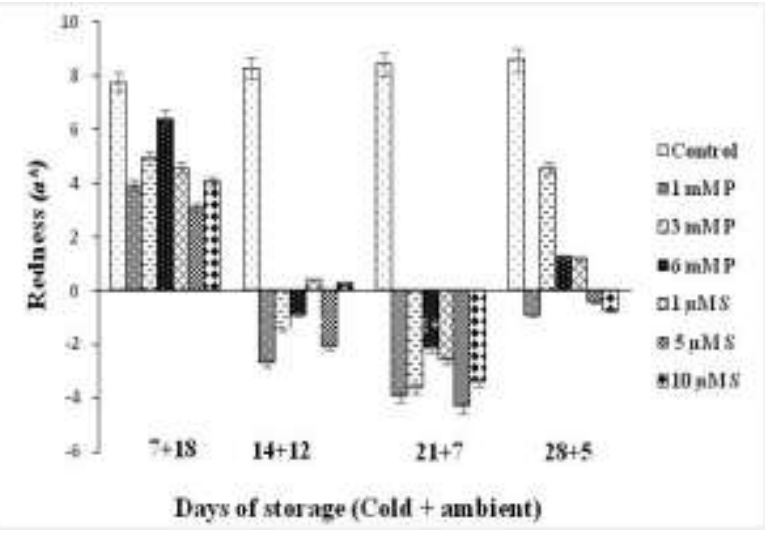


Figure.3 Effect of putrescine and spermine on TSS (a), Ascorbic acid (b) and Titratable acidity (c) of banana cv. Grand Naine stored at $13{ }^{\circ} \mathrm{C} \pm 1$ followed by ripening at room temperature. The results represent the mean of 3 fruits \pm S.E

$3(\mathrm{a})$

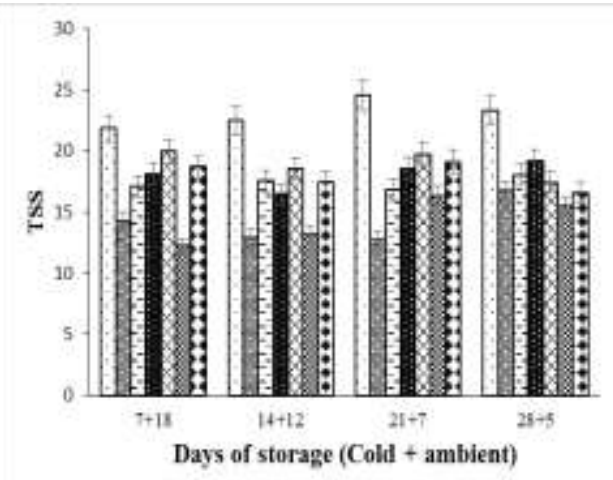

3(b)

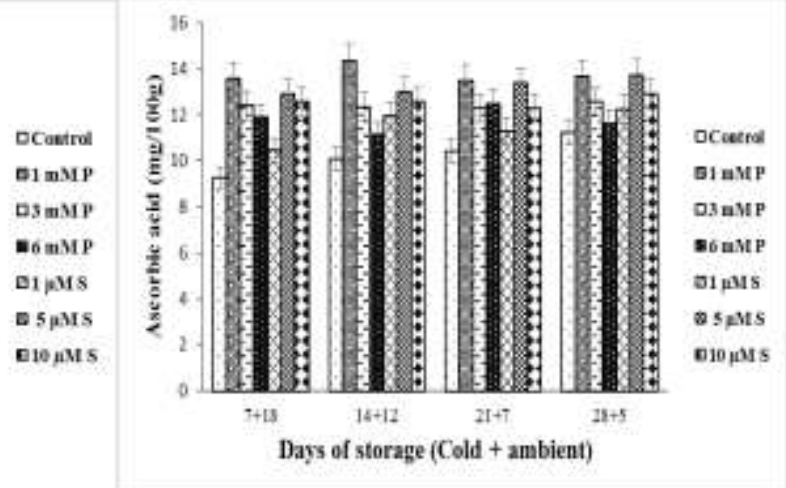

$3(\mathrm{c})$

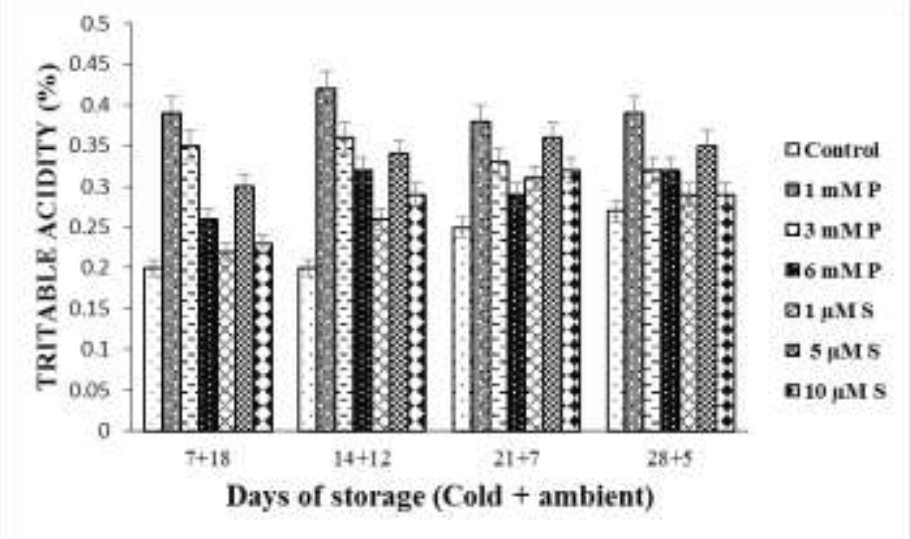

Figure.4 Effect of putrescine and spermine on Total sugar (a) and starch (b) of banana cv. Grand Naine stored at $13{ }^{\circ} \mathrm{C} \pm 1$ followed by ripening at room temperature. The results represent the mean of 3 fruits \pm S.E.

4(a)

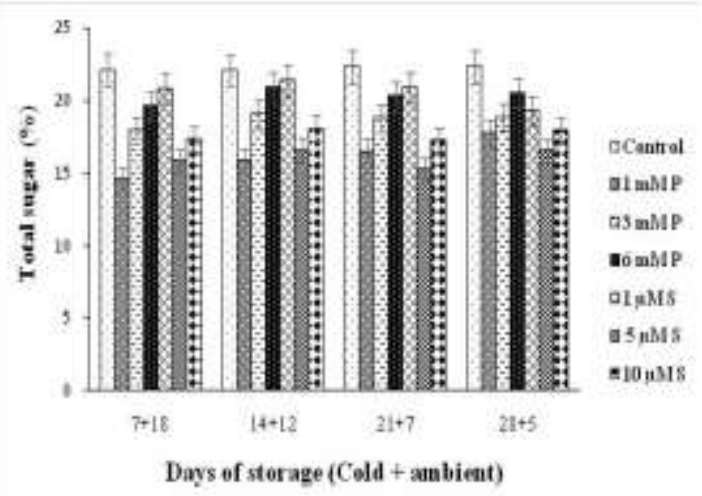

4(b)

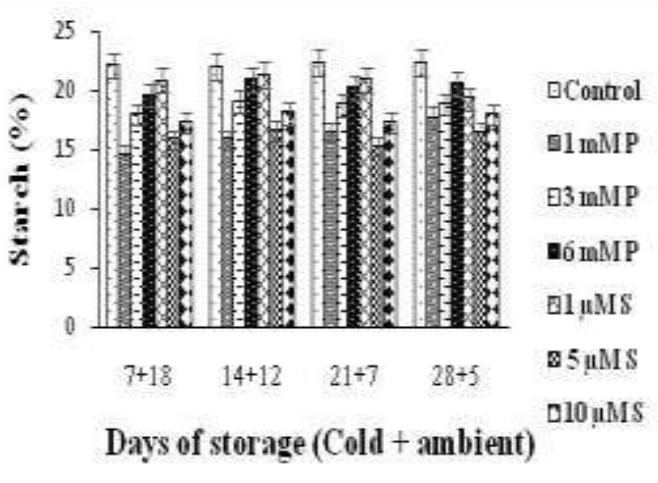


Figure.5 Effect of putrescine and spermine on organoleptic acceptability of banana cv. Grand Naine stored at $13{ }^{\circ} \mathrm{C} \pm 1$ followed by ripening at room temperature. The results represent the mean of 3 fruits \pm S.E.

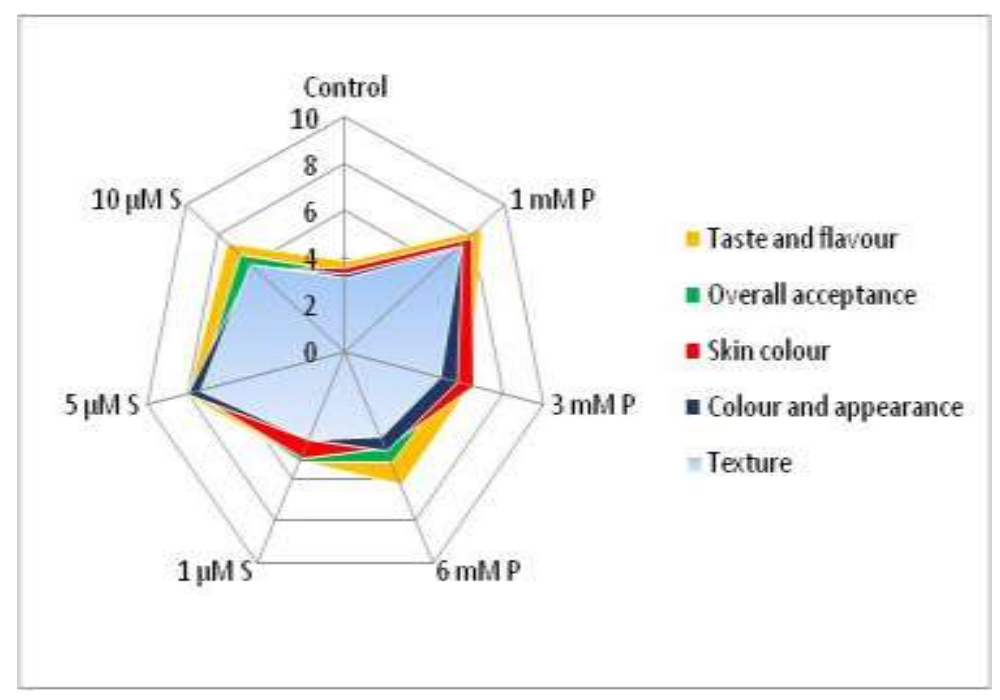

The taste and flavour is maintained by PUT and SPM treated fruits due to delayed ripening while it reduced in untreated fruits as fruits were in senescence stage at the end of the storage period. The high score for overall acceptability of fruits obtained in these treatments $(1 \mathrm{mM}$ PUT and $5 \mu \mathrm{M})$ may be due to good appearance, better texture and skin colour. The post-harvest dip treatment of PUT and SPM resulted in better organoleptic quality, especially in terms of flesh texture, colour and appearance, and taste. The similar findings are reported in $(4,27)$, mango (11) and in strawberry (13).

In conclusion, exogenous application of PUT and SPM improve the quality and storability of banana fruits cv. Grand Naine. The improvement in the storage potential of treated fruits was evident from the reduction in postharvest metabolic rate, delay in ripening, and increase in nutritional quality (titratable acidity and ascorbic acid) with sensory acceptability. However among the two polyamine treatments the $5 \mu \mathrm{MSPM}$ was found to be more effective. Although the synthetic polyamines available in market are expensive, the effectiveness of chemical at very lower concentration dose makes it economically feasible. Postharvest application of polyamine could be simple and effective technique to control the postharvest loss of banana fruits with improvement in quality and shelf life under cold storage $\left(13^{\circ} \mathrm{C} \pm 1\right)$.

\section{References}

1. Barman K, Asrey R, Pal RK(2011) Influence of putrescine and carnauba wax on functional and sensory quality of pomegranate (Punica granatum L.) fruits during storage. SciHort130: 795800.

2. Bregoli A, Scaramagli S, Costa G, Sabatini E, Ziosi V,Biondi S, Torrigiani P (2002) Peach (Prunus persica) fruit ripening: aminoethoxy vinylglycine (AVG) and exogenous polyamines affect ethylene emission and flesh firmness. Physiol Plant, 114:472-481.

3. Champa HWA, Gill MIS, Mahajan BVC, Arora NK, (2014) Postharvest treatment of polyamines maintains 
quality and extends shelf-life of table grapes (Vitis vinifera L.) cv. Flame Seedless. Postharvest BiolTechnol91: 57-63.

4. Champa HWA, Gill MIS, Mahajan BVC, Seema B (2015)Exogenous treatment of spermine to maintain quality and extend postharvest life of table grapes (Vitis vinifera L.) cv. Flame Seedless under low temperature storage. LWT- Food Sci Technol 60:412-419.

5. Dibble, ARG, Davies PJ, Mutschler MA (1988) Polyamine content of long keeping Alcobacca tomato fruit. Plant Physiol 86: 338-340.

6. Fariborz H, Asghar R (2017) Vacuum infiltration of putrescine enhances bioactive compounds and maintains quality of blood orange during cold storage. Food Chem 227: 1-8.

7. Galston AW, Kaur-Sawhney R (1990) Polyamines in plant physiology. Plant Physiol94:406-410.

8. Gholamhossein D, Mehdi Z, Elham A, Mohamad EN (2013) Influence of putrescine application on storability, postharvest quality and antioxidant activity of two Iranian apricot (Prunus armeniaca L.) cultivars. Not Sci Biol 5(2): 212-219.

9. Hubbard NL, Pharr DM, HuberSC (1990) Role of sucrose phosphate synthase in sucrose biosynthesis in ripening bananas and its relationship to the respiratory climacteric. Plant Physio 199: 201-208.

10. Jameel J, Sharma RR (2012) Effect of postharvest treatments with polyamines on physiological and biochemical attributes of kiwifruit (Actinidia deliciosa) cv. Allison. Fruits 67:13-22.

11. Jawandha SK, Gill MS, Gill PP, Singh $\mathrm{N}$ (2012) Effect of postharvest of putrescine on storage of mango cv. Langra. Afr J Agric Res 7(48): 6432-
6436.

12. Kashif R, Ahmad SK, Aman UM, Muhammad S, Sami U (2014)Role of putrescine in regulating fruit softening and antioxidative enzyme systems in 'Samar Bahisht Chaunsa' mango. Postharvest BiolTechnol. 96: 23-32.

13. Khosroshahi M, Ashari, M, Ershadi, A (2007) Effect of exogenous putrescine on post-harvest life of strawberry fruit, cv. Selva. Sci Hort., 114:27-32.

14. Lester, GE (2000) Polyamines and their cellular anti-senescence properties in honey dew muskmelon fruit. Plant Sci., 160:105-112.

15. Malik AU, Singh Z (2003) Exogenous application of putrescine affects mango shelf life and fruit quality. Acta Hortic., 628:121-127.

16. Malik A.U, Singh Z, Tan SC (2006) Exogenous application of polyamines improves shelf life and fruit quality in mango. Acta Hortic., 699: 291-296

17. Martinez RD, Serrano M, Carbonell A, Burgos OL, Riquelme F, Valero D (2002) Effect of post -harvest putrescine treatment on extending shelf life and reducing mechanical damage in apricot. J Food Sci., 67: 1706-1712.

18. Mirdehgha, H, Rahem M, Castillo S, Martinez D, Serrano M, Valero D (2007) Pre-storage application of polyamines by pressure or immersion improves shelf-life of pomegranate stored at chilling temperature by increasing endogenous polyamine levels. Postharvest Biol Technol 44:2633.

19. Mo H, Pua C (2002) Up-regulation of arginine decarboxylase gene expression and accumulation of polyamines in mustard (Brassica juncea). Physiol Plant 1114: 439-449.

20. Pandey S, Ranade SA, Nagar A, Nikhil K (2000) Role of polyamines and ethylene as modulators of plant 
senescence. Journal of bioscience 25:291-299.

21. Panse VS, Sukhatme PV (1985) Statistical methods for agricultural workers. Indian council of Agricultural Research (ed), New Delhi, pp 152-155.

22. Ranganna S (1999) Handbook of analysis and quality control for fruits and vegetable Products, 2nd edn. Tata McGraw-Hill Publishing Company Ltd, New Delhi.

23. Savithri N, Avtar, H, Autar, M (2008) Postharvest biology and technology of fruits, vegetables and flowers. Gopinandha, P., Dennis, P., Avtar, K. and Susan L (ed). pp 319-340.

24. Serrano M, Martinez-RomeroD, Guillen F, Valero D (2003) Effects of exogenous putrescine on improving shelf life of four plum cultivar. Postharvest Bio Technol 30: 259-271.

25. Seymour GB, Taylor JE, Tucker GA (1993) Biochemistry of fruit ripening. Chapman and Hall (ed), London, pp 83-106.

26. Shafiee M, Taghavi, TS Babalar M(2010) Addition of salicylic acid to nutrient solution combined with postharvest treatments (hot water, salicylic acid and calcium dipping) improved postharvest fruit quality of strawberry. SciHort 124:40-45.
27. Shiri MA, Ghasemnezhad M, Bakhshi D, Sarikhnai H (2013) Effect of postharvest putrescine application and chitosan coating on maintaining quality of table grape cv. "Shahroudi" during long-term storage. J Food Process Preser 37: 99-1007.

28. Srivastava RP, Sanjeev Kumar (2002) Fruit and Vegetable Preservation, Principles and Practices. 3rdedn. Army printing press Lucknow. India,pp 11-20

29. Stover RH, Simmonds NW (1987) Banana, 3rdedn. Longman, London.

30. Valero D, Romero M, Serrano M (2002) The role of polyamines in the improvement of the shelf life of fruits. Trends Food SciTechnol 13:228-234.

31. Valero D, Romero M, Serrano M, Riquelme F (1998) Influence of postharvest treatment with putrescine and calcium on endogenous polyamines, firmness, and abscisic acid in lemon (Citrus lemon L Burm cv. Verna). J Agric Food Chem 46:21022109.

32. Zienab, FR, Ahmeda B, Jiwan P, Paltab (2016) Postharvest dip treatment with a natural lysophospholipid plus soy lecithin extended the shelf life of banana fruit, Postharvest Bio Technol 113:58-65.

\section{How to cite this article:}

Archana, T.J. and Suresh, G.J. 2019. Putrescine and Spermine Affects the Postharvest Storage Potential of Banana Cv. Grand Naine. Int.J.Curr.Microbiol.App.Sci. 8(01): 3127-3137. doi: https://doi.org/10.20546/ijcmas.2019.801.334 